Review

\title{
Evidence that Vitamin D Supplementation Could Reduce Risk of Influenza and COVID-19 Infections and Deaths
}

\author{
William B. Grant ${ }^{1, *(\mathbb{D}}$, Henry Lahore ${ }^{2}$, Sharon L. McDonnell ${ }^{3}$, Carole A. Baggerly $^{3}{ }^{\circledR}$, \\ Christine B. French ${ }^{3}{ }^{(\mathbb{D}}$, Jennifer L. Aliano ${ }^{3}$ and Harjit P. Bhattoa ${ }^{4}$ \\ 1 Sunlight, Nutrition, and Health Research Center, P.O. Box 641603, San Francisco, CA 94164-1603, USA \\ 22289 Highland Loop, Port Townsend, WA 98368, USA; hlahore@vitamindwiki.com. \\ 3 GrassrootsHealth, Encinitas, CA 92024, USA; Sharon@grassrootshealth.org (S.L.M.); \\ carole@grassrootshealth.org (C.A.B.); Christine@grassrootshealth.org (C.B.F.); \\ jen@grassrootshealth.org (J.L.A.) \\ 4 Department of Laboratory Medicine, Faculty of Medicine, University of Debrecen, Nagyerdei Blvd 98, \\ H-4032 Debrecen, Hungary; harjit@med.unideb.hu \\ * Correspondence: wbgrant@infionline.net; Tel.: +1-415-409-1980
}

Received: 12 March 2020; Accepted: 31 March 2020; Published: 2 April 2020

\begin{abstract}
The world is in the grip of the COVID-19 pandemic. Public health measures that can reduce the risk of infection and death in addition to quarantines are desperately needed. This article reviews the roles of vitamin $\mathrm{D}$ in reducing the risk of respiratory tract infections, knowledge about the epidemiology of influenza and COVID-19, and how vitamin D supplementation might be a useful measure to reduce risk. Through several mechanisms, vitamin D can reduce risk of infections. Those mechanisms include inducing cathelicidins and defensins that can lower viral replication rates and reducing concentrations of pro-inflammatory cytokines that produce the inflammation that injures the lining of the lungs, leading to pneumonia, as well as increasing concentrations of anti-inflammatory cytokines. Several observational studies and clinical trials reported that vitamin D supplementation reduced the risk of influenza, whereas others did not. Evidence supporting the role of vitamin D in reducing risk of COVID-19 includes that the outbreak occurred in winter, a time when 25-hydroxyvitamin $\mathrm{D}(25(\mathrm{OH}) \mathrm{D})$ concentrations are lowest; that the number of cases in the Southern Hemisphere near the end of summer are low; that vitamin D deficiency has been found to contribute to acute respiratory distress syndrome; and that case-fatality rates increase with age and with chronic disease comorbidity, both of which are associated with lower $25(\mathrm{OH}) \mathrm{D}$ concentration. To reduce the risk of infection, it is recommended that people at risk of influenza and/or COVID-19 consider taking $10,000 \mathrm{IU} / \mathrm{d}$ of vitamin $\mathrm{D}_{3}$ for a few weeks to rapidly raise $25(\mathrm{OH}) \mathrm{D}$ concentrations, followed by $5000 \mathrm{IU} / \mathrm{d}$. The goal should be to raise 25(OH)D concentrations above $40-60 \mathrm{ng} / \mathrm{mL}(100-150 \mathrm{nmol} / \mathrm{L})$. For treatment of people who become infected with COVID-19, higher vitamin $\mathrm{D}_{3}$ doses might be useful. Randomized controlled trials and large population studies should be conducted to evaluate these recommendations.
\end{abstract}

Keywords: acute respiratory distress syndrome (ARDS); ascorbic acid; cathelicidin; coronavirus; COVID-19; cytokine storm; influenza; observational; pneumonia; prevention; respiratory tract infection; solar radiation; treatment; UVB; vitamin C; vitamin D

\section{Introduction}

The world is now experiencing its third major epidemic of coronavirus $(\mathrm{CoV})$ infections. A new CoV infection epidemic began in Wuhan, Hubei, China, in late 2019, originally called 2019-nCoV [1] 
and renamed COVID-19 by the World Health Organization on February 11, 2020. Previous CoV epidemics include severe acute respiratory syndrome (SARS)-CoV, which started in China in 2002 [2], and the ongoing Middle East respiratory syndrome (MERS)-CoV in the Middle East, first reported in 2012 [3]. Those epidemics all began with animal-to-human infection. The direct cause of death is generally due to ensuing severe atypical pneumonia $[4,5]$.

Seasonal influenza has a high health burden. According to one recent estimate, 389,000 (uncertainty range 294,000-518,000) respiratory deaths were associated with influenza during the period 2002-2011 [6]. According to the U.S. Center for Disease Control and Prevention, during the period 2010-2019, annual symptomatic illness affected between 9 and 45 million people, resulting in between 4 and 21 million medical visits, 140,000-810,000 hospitalizations, and 23,000-61,000 deaths (https://www.cdc.gov/flu/about/burden/).

This review is a narrative one. Searches were made in PubMed.gov and scholar.google. com for publications regarding influenza, CoVs, COVID-19, and pneumonia with respect to epidemiology, innate and adaptive immune response, vitamin $\mathrm{D}, 25$-hydroxyvitamin $\mathrm{D}(25(\mathrm{OH}) \mathrm{D})$, and parathyroid hormone.

\section{Vitamin D and Mechanisms to Reduce Microbial Infections}

The general metabolism and actions of vitamin $\mathrm{D}$ are well known [7]. Vitamin $\mathrm{D}_{3}$ is produced in the skin through the action of UVB radiation reaching 7-dehydrocholesterol in the skin, followed by a thermal reaction. That vitamin $\mathrm{D}_{3}$ or oral vitamin $\mathrm{D}$ is converted to $25(\mathrm{OH}) \mathrm{D}$ in the liver and then to the hormonal metabolite, $1,25(\mathrm{OH})_{2} \mathrm{D}$ (calcitriol), in the kidneys or other organs as needed. Most of vitamin D's effect arises from calcitriol entering the nuclear vitamin D receptor, a DNA binding protein that interacts directly with regulatory sequences near target genes and that recruits chromatin active complexes that participate genetically and epigenetically in modifying transcriptional output [8]. A well-known function of calcitriol is to help regulate serum calcium concentrations, which it does in a feedback loop with parathyroid hormone (PTH), which itself has many important functions in the body [7].

Several reviews consider the ways in which vitamin D reduces the risk of viral infections [9-17].

Vitamin D has many mechanisms by which it reduces the risk of microbial infection and death. A recent review regarding the role of vitamin $\mathrm{D}$ in reducing the risk of the common cold grouped those mechanisms into three categories: physical barrier, cellular natural immunity, and adaptive immunity [16]. Vitamin D helps maintain tight junctions, gap junctions, and adherens junctions (e.g., by E-cadherin) [18]. Several articles discussed how viruses disturb junction integrity, increasing infection by the virus and other microorganisms [19-21].

Vitamin D enhances cellular innate immunity partly through the induction of antimicrobial peptides, including human cathelicidin, LL-37, by 1,25-dihdroxyvitamin D [22,23], and defensins [24]. Cathelicidins exhibit direct antimicrobial activities against a spectrum of microbes, including Gram-positive and Gram-negative bacteria, enveloped and nonenveloped viruses, and fungi [25]. Those host-derived peptides kill the invading pathogens by perturbing their cell membranes and can neutralize the biological activities of endotoxins [26]. They have many more important functions, as described therein. In a mouse model, LL-37 reduced influenza A virus replication [27]. In another laboratory study, $1,25(\mathrm{OH})_{2} \mathrm{D}$ reduced the replication of rotavirus both in vitro and in vivo by another process [28]. A clinical trial reported that supplementation with $4000 \mathrm{IU} / \mathrm{d}$ of vitamin D decreased dengue virus infection [29].

Vitamin D also enhances cellular immunity, in part by reducing the cytokine storm induced by the innate immune system. The innate immune system generates both pro-inflammatory and anti-inflammatory cytokines in response to viral and bacterial infections, as observed in COVID-19 patients [30]. Vitamin D can reduce the production of pro-inflammatory Th1 cytokines, such as tumor necrosis factor $\alpha$ and interferon $\gamma$ [31]. Administering vitamin $\mathrm{D}$ reduces the expression 
of pro-inflammatory cytokines and increases the expression of anti-inflammatory cytokines by macrophages ([17] and references therein).

Vitamin D is a modulator of adaptive immunity [16,32]; $1,25(\mathrm{OH})_{2} \mathrm{D}_{3}$ suppresses responses mediated by the Thelper cell type 1 (Th1), by primarily repressing production of inflammatory cytokines IL-2 and interferon gamma (INF $\gamma$ ) [33]. Additionally, $1,25(\mathrm{OH})_{2} \mathrm{D}_{3}$ promotes cytokine production by the T helper type 2 (Th2) cells, which helps enhance the indirect suppression of Th1 cells by complementing this with actions mediated by a multitude of cell types [34]. Furthermore, $1,25(\mathrm{OH})_{2} \mathrm{D}_{3}$ promotes induction of the $\mathrm{T}$ regulatory cells, thereby inhibiting inflammatory processes [35].

Serum 25(OH)D concentrations tend to decrease with age [36], which may be important for COVID-19 because case-fatality rates (CFRs) increase with age [37]. Reasons include less time spent in the sun and reduced production of vitamin $\mathrm{D}$ as a result of lower levels of 7-dehydrocholesterol in the skin [38]. In addition, some pharmaceutical drugs reduce serum $25(\mathrm{OH}) \mathrm{D}$ concentrations by activating the pregnane- $X$ receptor [39]. Such drugs include antiepileptics, antineoplastics, antibiotics, anti-inflammatory agents, antihypertensives, antiretrovirals, endocrine drugs, and some herbal medicines. Pharmaceutical drug use typically increases with age.

Vitamin D supplementation also enhances the expression of genes related to antioxidation (glutathione reductase and glutamate-cysteine ligase modifier subunit) [40]. The increased glutathione production spares the use of ascorbic acid (vitamin C), which has antimicrobial activities [41,42], and has been proposed to prevent and treat COVID-19 [43]. Moreover, a former director of the Center for Disease Control and Prevention, Dr. Tom Frieden, proposed using vitamin D to combat the COVID-19 pandemic on 23 March 2020 (https://www.foxnews.com/opinion/former-cdc-chief-tomfrieden-coronavirus-risk-may-be-reduced-with-vitamin-d).

\section{Discussion}

\subsection{Seasonal Influenza}

Influenza virus affects the respiratory tract by direct viral infection or by damage to the immune system response. The proximate cause of death is usually from the ensuing pneumonia. Patients who develop pneumonia are more likely to be $<5$ years old, $>65$ years old, white, and nursing home residents, to have chronic lung or heart disease and a history of smoking, and to be immunocompromised [44].

Seasonal influenza infections generally peak in winter [45]. Cannell et al. hypothesized that the winter peak was due in part to the conjunction with the season when solar UVB doses, and thus $25(\mathrm{OH}) \mathrm{D}$ concentrations, are lowest in most mid- and high-latitude countries [46], extended in [47]. Mean serum 25(OH)D concentrations in north and central regions of the United States are near $21 \mathrm{ng} / \mathrm{mL}$ in winter and $28 \mathrm{ng} / \mathrm{mL}$ in summer, whereas in the south region, they are near $24 \mathrm{ng} / \mathrm{mL}$ in winter and $28 \mathrm{ng} / \mathrm{mL}$ in summer [48]. In addition, the winter peak of influenza also coincides with weather conditions of low temperature and relative humidity that allow the influenza virus to survive longer outside the body than under warmer conditions [49-51].

Ecological studies suggest that raising $25(\mathrm{OH}) \mathrm{D}$ concentrations through vitamin $\mathrm{D}$ supplementation in winter would reduce the risk of developing influenza. Table 1 presents results from randomized controlled trials (RCTs) investigating how vitamin D supplementation affects risk of influenza. The RCTs included confirmed that the respiratory tract infection was indeed derived from influenza. Only two RCTs reported beneficial effects: one among schoolchildren in Japan [52], the other among infants in China [53]. An RCT in Japan that reported no beneficial effect did not measure baseline 25(OH)D concentration [54] and included many participants who had been vaccinated against influenza (M. Urashima; private communication). The two most recent RCTs included participants with above average mean baseline $25(\mathrm{OH}) \mathrm{D}$ concentrations $[55,56]$. A comprehensive review of the role of vitamin D and influenza was published in 2018 [15]. It concluded that the evidence of vitamin D's effects on the immune system suggest that vitamin D should reduce the risk of influenza, but that 
more studies are required to evaluate that possibility. Large population studies would also be useful, in which vitamin D supplementation is also related to changes in serum $25(\mathrm{OH}) \mathrm{D}$ concentration.

Table 1. Results of vitamin D randomized controlled trials (RCTs) on risk of influenza.

\begin{tabular}{|c|c|c|c|c|c|c|}
\hline Country & Population & $\begin{array}{l}\text { Baseline } \\
25(\mathrm{OH}) \mathrm{D} \\
(\mathrm{ng} / \mathrm{mL})\end{array}$ & $\begin{array}{l}\text { Vitamin D } \\
\text { Dose } \\
\text { (IU/d) }\end{array}$ & $\begin{array}{c}\text { Influenza Cases in } \\
\text { Vitamin D, Placebo } \\
\text { Arms }\end{array}$ & Outcome & Ref \\
\hline Japan & $\begin{array}{l}\text { Schoolchildren } \\
\text { aged 6-15 yrs }\end{array}$ & N/A & 0,1200 & $\begin{array}{c}\text { Type A: } 18 / 167 ; 31 / 167 . \\
\text { If not taking vitamin } \\
\text { D before enrollment: } \\
\text { 8/140; } 22 / 140 \text {. Type B: } \\
\text { 39/167; } \\
\text { 28/167 }\end{array}$ & $\begin{array}{c}\text { Type A: RR }=0.58 \\
\text { ( } 95 \% \text { CI, } 0.34 \text { to } 0.99) ; \\
\text { if not taking vitamin } \\
\text { D before enrollment, } \\
\text { RR = } 0.36 \text { ( } 95 \% \text { CI, } \\
0.17 \text { to } 0.79) ; \\
\text { no effect for Type B }\end{array}$ & [52] \\
\hline Japan & $\begin{array}{c}\text { High school } \\
\text { students, } \\
\text { including many } \\
\text { vaccinated against } \\
\text { influenza } \\
\end{array}$ & N/A & 0,2000 & $20 / 148 ; 12 / 99$ & $\begin{array}{c}\text { Type A, RR }=1.11 \\
(95 \% \text { CI, } 0.57 \text { to } 2.18)\end{array}$ & [54] \\
\hline China & Infants, 3-12 mos & 17 & 400,1200 & & $\begin{array}{l}\text { Diff. in influenza A } \\
\text { viral load, high vs. } \\
\text { low vitamin D on day } \\
4 \text { of illness: } 1.3 \pm 0.5 \\
\text { vs. } 4.5 \pm 1.4 \times 10^{6} \\
\text { copies } / \mathrm{mL}\end{array}$ & [53] \\
\hline Japan & $\begin{array}{l}223 \text { patients } \\
\text { with IBD, } \\
\text { mean age } 45 \text { yrs }\end{array}$ & $23-24$ & 0,500 & $\begin{array}{l}8 / 115 \\
6 / 108\end{array}$ & $\begin{array}{c}\mathrm{RR}=1.25(95 \% \mathrm{CI} \\
0.45 \text { to } 3.49)\end{array}$ & [55] \\
\hline Vietnam & $\begin{array}{l}\text { Children aged } \\
3-17 \text { yrs }\end{array}$ & 26 & $\begin{array}{l}0,14,000 \\
/ \text { wk }\end{array}$ & $\begin{array}{l}50 / 650 \\
43 / 650\end{array}$ & $\begin{array}{c}\mathrm{HR}=1.18(95 \% \mathrm{CI}, \\
0.79 \text { to } 1.78)\end{array}$ & [56] \\
\hline
\end{tabular}

Note: $95 \%$ confidence interval (95\% CI); day (d); hazard ratio (HR); inflammatory bowel disease (IBD); months (mos); not available (N/A); relative risk (RR); upper respiratory tract infection (URTI); week (wk); years (yrs).

An observational study conducted in Connecticut on 198 healthy adults in the fall and winter of 2009-2010 examined the relationship between serum 25(OH)D concentration and incidence of acute RTIs (ARTIs) [57]. Only 17\% of people who maintained $25(\mathrm{OH}) \mathrm{D}>38 \mathrm{ng} / \mathrm{mL}$ throughout the study developed ARTIs, whereas $45 \%$ of those with $25(\mathrm{OH}) \mathrm{D}<38 \mathrm{ng} / \mathrm{mL}$ did. Concentrations of $38 \mathrm{ng} / \mathrm{mL}$ or more were associated with a significant $(p<0.0001)$ twofold reduction in risk of developing ARTIs and with a marked reduction in the percentage of days ill. Eight influenza-like illnesses (ILIs) occurred, seven of which were the 2009 H1N1 influenza.

\subsection{Clinical and Epidemiological Findings Regarding COVID-19}

The first step in developing a hypothesis is to outline the epidemiological and clinical findings regarding the disease of interest and their relationship with $25(\mathrm{OH}) \mathrm{D}$ concentrations. From the recent journal literature, it is known that COVID-19 infection is associated with the increased production of pro-inflammatory cytokines [58], C-reactive protein [30], increased risk of pneumonia [58], sepsis [59], acute respiratory distress syndrome [59], and heart failure [59]. CFRs in China were 6\%-10\% for those with cardiovascular disease, chronic respiratory tract disease, diabetes, and hypertension [37]. Two regions hard hit by COVID-19 are regions of high air pollution in China [60] and northern Italy [61].

The possible roles of vitamin $\mathrm{D}$ for the clinical and epidemiological characteristics of diseases associated with the increased risk of COVID-19 CFR are given in Table 2. Most of the beneficial effects of vitamin $\mathrm{D}$ given in Table 2 are from observational studies of disease incidence or prevalence with respect to serum $25(\mathrm{OH}) \mathrm{D}$ concentrations. RCTs comparing outcomes for participants treated or given a placebo are preferred to establish causality related to health outcomes. However, most vitamin $\mathrm{D}$ RCTs have not reported that vitamin D supplementation reduced the risk of disease [62,63]. Reasons for the lack of agreement between observational studies and RCTs seems to be due to several factors, 
including enrolling participants with relatively high $25(\mathrm{OH}) \mathrm{D}$ concentrations and using low vitamin $\mathrm{D}$ doses and not measuring baseline and achieved $25(\mathrm{OH}) \mathrm{D}$ concentrations. Previous studies proposed that RCTs of nutrients such as vitamin D be based on nutrient status, such as $25(\mathrm{OH}) \mathrm{D}$ concentration, seeking to enroll participants with low values, supplementing them with enough agent to raise the concentration to values associated with good health, and measuring achieved concentrations as well as cofactors such as vitamin C, omega-3 fatty acids, and magnesium [64,65],. Two recently completed RCTs reported significantly reduced incidence in the secondary analyses for cancer [66] and diabetes mellitus [67].

Table 2. How vitamin D is related to the clinical and epidemiological findings for incidence and case-fatality rates.

\begin{tabular}{|c|c|c|}
\hline Characteristics & Relation to $25(\mathrm{OH}) \mathrm{D}$ & Reference \\
\hline \multicolumn{3}{|l|}{ Clinical } \\
\hline Severe cases associated with pneumonia & Inverse correlation for CAP & {$[68,69]$} \\
\hline $\begin{array}{l}\text { Increased production of pro-inflammatory } \\
\text { cytokines such as IL-6 }\end{array}$ & Inverse correlation & {$[70,71]$} \\
\hline Increased CRP & Inverse correlation & {$[72,73]$} \\
\hline Increased risk of sepsis & Inverse correlation & {$[74,75]$} \\
\hline Risk of ARDS & Inverse correlation & {$[76,77]$} \\
\hline Risk of heart failure & Inverse correlation & {$[78,79]$} \\
\hline Risk of diabetes mellitus & Inverse correlation & {$[67,80]$} \\
\hline \multicolumn{3}{|l|}{ Epidemiological } \\
\hline $\begin{array}{l}\text { Began in December } 2019 \text { in China, spread } \\
\text { mainly to northern midlatitude countries }\end{array}$ & Low $25(\mathrm{OH}) \mathrm{D}$ values in winter & {$[48,81]$} \\
\hline $\begin{array}{l}\text { Males have higher incidence and much } \\
\text { higher CFRs than females }\end{array}$ & Smoking reduces $25(\mathrm{OH}) \mathrm{D}$ & [82] \\
\hline CFR increases with age & $\begin{array}{l}\text { Chronic disease rates increase with age; } \\
\text { vitamin D plays a role in reducing risk of } \\
\text { chronic diseases }\end{array}$ & [83] \\
\hline Higher CFR for diabetics & Diabetics may have lower 25(OH)D & [84] \\
\hline Higher CFR for diabetics & $\begin{array}{c}\text { Lower } 25(\mathrm{OH}) \mathrm{D} \text { associated with increased } \\
\text { risk of incidence }\end{array}$ & {$[85]$} \\
\hline Higher CFR for hypertension & $\begin{array}{l}\text { Lower 25(OH)D may be associated with } \\
\text { increased risk of incidence }\end{array}$ & [86] \\
\hline Higher CFR for cardiovascular disease & $\begin{array}{c}\text { Lower } 25(\mathrm{OH}) \mathrm{D} \text { associated with increased } \\
\text { risk of incidence and death }\end{array}$ & [87] \\
\hline Higher CFR for chronic respiratory disease & $\begin{array}{c}\text { For COPD patients, } 25(\mathrm{OH}) \mathrm{D} \text { inversely } \\
\text { correlated with risk, severity, and } \\
\text { exacerbation }\end{array}$ & [88] \\
\hline $\begin{array}{l}\text { Found at higher rates in regions with } \\
\text { elevated air pollution }\end{array}$ & $\begin{array}{l}\text { Air pollution associated with lower } 25(\mathrm{OH}) \mathrm{D} \\
\text { concentrations }\end{array}$ & [89] \\
\hline
\end{tabular}

Table 3 lists some findings for vitamin D supplementation in reducing the clinical effects of COVID-19 infection found from treating other diseases. 
Table 3. How vitamin D supplementation is related to the clinical and epidemiological findings for treatment.

\begin{tabular}{|c|c|c|}
\hline Clinical Characteristics & Findings from Vitamin D Supplementation Trials & Reference \\
\hline Treatment of CAP with vitamin D & $\begin{array}{c}\text { Did not significantly result in complete resolution. } \\
\text { Baseline } 25(\mathrm{OH}) \mathrm{D} \text { was } 20 \mathrm{ng} / \mathrm{ml} \text {. Achieved } 25(\mathrm{OH}) \mathrm{D} \text { in } \\
\text { the treatment arm was } 40 \mathrm{ng} / \mathrm{mL} \text {. }\end{array}$ & {$[90]$} \\
\hline $\begin{array}{l}\text { Increased production of } \\
\text { pro-inflammatory cytokines such } \\
\text { as IL-6 }\end{array}$ & Reduces concentration of IL-6 & [11] \\
\hline Increased CRP & Reduces CRP in diabetic patients & [91] \\
\hline Increased risk of sepsis & $\begin{array}{l}\text { No reduction in mortality rate found for adults with } \\
\text { sepsis supplemented with vitamin } \mathrm{D} \text {. Most trials } \\
\text { included participants with } 25(\mathrm{OH}) \mathrm{D}<20 \mathrm{ng} / \mathrm{mL} \text {; } \\
\text { vitamin } \mathrm{D}_{3} \text { doses between } 250 \text { and } 600 \text { thousand IU. }\end{array}$ & [92] \\
\hline Risk of ARDS & $\begin{array}{l}\text { Vitamin D deficiency contributes to development of } \\
\text { ARDS }\end{array}$ & {$[77,93]$} \\
\hline
\end{tabular}

A possible reason for the monotonic increase in CFR with increasing age could be that the presence of chronic diseases increases with age. For example, the global prevalence of diabetes mellitus increases from about $1 \%$ below the age of 20 years, to $~ 10 \%$ at 45 years and to $19 \%$ at 65 years, decreasing to $14 \%$ by 95 years [94]. Invasive lung cancer incidence rates for females in the United States in 2015 increased from 1.1/100,000 for those aged 30-34 years, to 51.0/100,000 for those aged 50-54 years, 204.1/100,000 for those aged 65-79 years, and 347.3 for those aged 75-79 years [95]. Several studies report that people with chronic diseases have lower $25(\mathrm{OH}) \mathrm{D}$ concentrations than healthy people. A study in Italy reported that male chronic obstructive pulmonary disease patients had mean $25(\mathrm{OH}) \mathrm{D}$ concentrations of $16(95 \% \mathrm{CI}, 13-18) \mathrm{ng} / \mathrm{mL}$, whereas female patients had concentrations of $13(95 \%$ $\mathrm{CI}, 11-15) \mathrm{ng} / \mathrm{ml}$ [96]. A study in South Korea reported that community-acquired pneumonia (CAP) patients had a mean 25(OH)D concentration at admission of $14 \pm 8 \mathrm{ng} / \mathrm{mL}$ [97]. A study in Iran reported that hypertensive patients had lower $25(\mathrm{OH}) \mathrm{D}$ concentrations than control subjects: males, $13 \pm 11 \mathrm{vs}$. $21 \pm 11 \mathrm{ng} / \mathrm{mL}$; females, $13 \pm 10$ vs. $20 \pm 11 \mathrm{ng} / \mathrm{mL}$ [98]

Another factor that affects immune response with age is reduced 1,25-dihydroxyvitamin D $\left(1,25(\mathrm{OH})_{2} \mathrm{D}\right.$, or calcitriol), the active vitamin D metabolite, with increased age. Parathyroid hormone (PTH) concentration increases with age. A U.S. study was based on 312,962 paired serum PTH and 25(OH)D concentration measurements from July 2010 to June 2011. For participants with 20-ng/mL 25(OH)D concentration, PTH increased from $27 \mathrm{pg} / \mathrm{mL}$ for those $<20$ years to $54 \mathrm{pg} / \mathrm{mL}$ for those $>60$ years [99]. Serum calcitriol concentrations are inversely related to PTH concentrations. In a study conducted in Norway on patients with a mean age of 50 (SD, 21) years, calcitriol decreased from $140 \mathrm{pmol} / \mathrm{L}$ for those aged $20-39$ years to $98 \mathrm{pmol} / \mathrm{L}$ for those $>80$ years despite an increase in serum 25(OH)D from $24 \mathrm{ng} / \mathrm{mL}$ for those $20-39$ years to $27 \mathrm{ng} / \mathrm{mL}$ for those $>80$ years [100].

The seasonality of many viral infections is associated with low $25(\mathrm{OH}) \mathrm{D}$ concentrations, as a result of low UVB doses owing to the winter in temperate climates and the rainy season in tropical climates-such as respiratory syncytial virus (RSV) infection [101,102],. This is the case for influenza [45, 46], and SARS-CoV [103]. However, MERS showed a peak in the April-June quarter [104], probably affected by both Hajj pilgrims gathering and the fact that 25(OH)D concentrations show little seasonal variation in the Middle East [105]. In the tropics, seasonality is related more to rainy periods (low UVB doses), for example, for influenza [106].

Considerable indirect evidence is inferred from effects found for other enveloped viruses. Table 4 presents the findings from various studies. 
Table 4. Findings regarding the associations and effects of vitamin D on enveloped viral infections.

\begin{tabular}{|c|c|c|}
\hline Virus & Vitamin D Effect & Reference \\
\hline Dengue & Vitamin D mechanisms discussed & [107] \\
\hline Dengue & $\begin{array}{c}\text { Inverse association between } 25(\mathrm{OH}) \mathrm{D} \text { concentration and progression of } \\
\text { disease state }\end{array}$ & [108] \\
\hline Dengue & $\begin{array}{l}\text { Vitamin D supplementation trial with } 1000 \text { and } 4000 \mathrm{IU} / \mathrm{d} .4000 \mathrm{IU} / \mathrm{d} \\
\text { resulted in higher resistance to DENV-2 infection. MDDCs from those } \\
\text { supplemented with } 4000 \text { IU/d showed decreased mRNA expression of } \\
\text { TLR3, 7, and 9; downregulation of IL-12/IL-8 production; and increased } \\
\text { IL-10 secretion in response to DENV-2 infection }\end{array}$ & [29] \\
\hline Hepatitis C & $\begin{array}{l}\text { 1,25-hydroxyvitamin-D3-24-hydroxylase, encoded by CYP24A1 gene, is } \\
\text { a key enzyme that neutralizes } 1,25(\mathrm{OH})_{2} \mathrm{D} \text {. This study found that alleles } \\
\text { of CYP24A1 had different effects on risk of chronic hepatitis } \mathrm{C} \text { infection. }\end{array}$ & [109] \\
\hline $\mathrm{CHB}$ & $\begin{array}{l}25(\mathrm{OH}) \mathrm{D} \text { concentrations were lower in CHB patients than that of } \\
\text { healthy controls and inversely correlated with HBV viral loads }\end{array}$ & [110] \\
\hline KSHV & $\begin{array}{c}\text { Found that cathelicidin significantly reduced KSVH by disrupting the } \\
\text { viral envelope. }\end{array}$ & [111] \\
\hline HIV-1 & $\begin{array}{l}\text { Review of } 29 \text { clinical studies of vitamin D supplementation showed } \\
\text { there was a decrease in inflammation. In } 3 \text { of } 7 \text { studies, CD } 4+\text { T cell } \\
\text { count increased, but effect on viral load was inconclusive since most } \\
\text { patients were on cART. }\end{array}$ & [112] \\
\hline H9N2 influenza & $\begin{array}{l}\text { In a lung epithelial cell study, calcitriol treatment prior to and post } \\
\text { infection with H9N2 influenza significantly decreased expression of the } \\
\text { influenza M gene, IL-6, and IFN- } \beta \text { in A549 cells, but did not affect virus } \\
\text { replication. }\end{array}$ & [113] \\
\hline RSV & $\begin{array}{l}\text { Demonstrated that the human cathelicidin LL- } 37 \text { has effective antiviral } \\
\text { activity against RSV in vitro and prevented virus-induced cell death in } \\
\text { epithelial cultures, }\end{array}$ & [114] \\
\hline RSV & $\begin{array}{l}\text { Performed a laboratory study that identified the mechanism by which } \\
\text { vitamin D reduced risk of RSV. }\end{array}$ & [28] \\
\hline RSV & $\begin{array}{c}\text { Found that the T-allele of the vitamin D receptor has a lower prevalence } \\
\text { in African populations and runs parallel to the lower incidence of } \\
\text { RSV-associated severe ALRI in African children, } 1 \text { year. }\end{array}$ & [115] \\
\hline Rotaviral diarrhea & $\begin{array}{l}\text { Found serum } 25(\mathrm{OH}) \mathrm{D}<20 \mathrm{ng} / \mathrm{mL} \text { associated with an odds ratio of } 6.3 \\
\qquad(95 \% \mathrm{CI}, 3.6 \text { to } 10.9) \text { for rotaviral diarrhea }\end{array}$ & [116] \\
\hline
\end{tabular}

Note: acute respiratory tract infection (ALRI); combination Antiretroviral Therapy (cART); chronic hepatitis B (CHB); dengue virus-2 (DENV-2). Human immunodeficiency virus 1 (HIV-1); Kaposi's sarcoma-associated herpesvirus (KSHV); monocyte-derived dendritic cells (MDDCs); respiratory syncytial virus (RSV).

One way that CoVs injure the lung epithelial cells and facilitate pneumonia is through increased production of Th1-type cytokines as part of the innate immune response to viral infections, giving rise to the cytokine storm. A laboratory cell study reported that interferon $\gamma$ is responsible for acute lung injury during the late phase of the SARS-CoV pathology [117].

Pro-inflammatory cytokine storms from $\mathrm{CoV}$ infections have resulted in the most severe cases for SARS-CoV [118] and MERS-CoV [119]. However, COVID-19 infection also initiated increased secretion of the Th2 cytokines (e.g., interleukins 4 and 10) that suppress inflammation, which differs from SARS-CoV infection [30].

\subsection{Pneumonia}

An example of the role of vitamin $\mathrm{D}$ in reducing the risk of death from pandemic respiratory tract infections is found in a study of CFRs resulting from the 1918-1919 influenza pandemic in the United States [120]. The U.S. Public Health Service conducted door-to-door surveys of 12 communities from 
New Haven, Connecticut, to San Francisco, California, to ascertain incidence and CFRs. The canvasses were made as soon as possible after the autumn 1918 wave of the epidemic subsided in each locality. A total of 146,203 people, 42,920 cases, and 730 deaths were found. As shown in their Table 25, fatality rates averaged 1.70 per 100 influenza cases but averaged 25.5 per 100 cases of pneumonia. The percentage of influenza complicated by pneumonia was $6.8 \%$. The pneumonia CFR (excluding Charles County, MD, because of inconsistencies in recording cause of death) was 28.8 per 100 for whites and 39.8 per 100 for "coloreds". As shown in Table 23, "coloreds" in the southeastern states had between a $27 \%$ and $80 \%$ higher rate of pneumonia compared to whites. As discussed in an ecological study using those CFR data, communities in the southwest had lower CFR than those in the northeast because of higher summertime and wintertime solar UVB doses [121]. Previous work suggested that higher UVB doses were associated with higher $25(\mathrm{OH}) \mathrm{D}$ concentrations, leading to reductions in the cytokine storm and the killing of bacteria and viruses that participate in pneumonia. African Americans had much higher mortality rates than white Americans for the period 1900-1948 [122]. The reasons CFRs were higher for "coloreds" than whites may include that they have higher rates of chronic diseases, are more likely to live in regions impacted by air pollution, and that with darker skin pigmentation, blacks have lower $25(\mathrm{OH}) \mathrm{D}$ concentrations. A clinical trial involving postmenopausal women living on Long Island, NY with mean baseline $25(\mathrm{OH}) \mathrm{D}$ concentration $19 \pm 8 \mathrm{ng} / \mathrm{mL}$ found that supplementation with $2000 \mathrm{IU} / \mathrm{d}$ resulted in significantly fewer upper respiratory tract infections, including influenza, than a placebo or supplementation with $800 \mathrm{IU} / \mathrm{d}$ [123]. See, also, references in [11]. An analysis of serum 25(OH)D concentrations by race for 2001-2004 indicated mean 25(OH)D concentrations for people over 40 years: non-Hispanic whites, $25-26 \mathrm{ng} / \mathrm{mL}$; non-Hispanic blacks, 14-17 ng/mL; Mexican-Americans, 18-22 ng/mL [124]. A reason proposed for the higher mortality rates in some communities during the 1918-1919 influenza pandemic was that they were near to coal-fired electricity generating plants [125]. Recent studies have confirmed that air pollution, from combustion sources, increases the risk of influenza [126,127]. The highest concentration of these plants is in the northeast, where solar UVB doses are lowest.

A high-dose $(250,000$ or $500,000 \mathrm{IU})$ vitamin $\mathrm{D}_{3}$ trial in ventilated intensive care unit patients in Georgia with mean a baseline $25(\mathrm{OH}) \mathrm{D}$ concentration of 20-22 ng/mL reported that hospital length of stay was reduced from 36 (SD, 19) days in the control group to 25 (SD, 14) days in the 250,000-IU group $[25(\mathrm{OH}) \mathrm{D}=45 \pm 20 \mathrm{ng} / \mathrm{mL}]$ and $18(\mathrm{SD}, 11)$ days in the 500,000-IU group $[25(\mathrm{OH}) \mathrm{D}=55 \pm$ $14 \mathrm{ng} / \mathrm{mL}$ ]; $p=0.03$ [93]. In a follow-on pilot trial involving 30 mechanically ventilated critically ill patients, 500,000 IU of vitamin $\mathrm{D}_{3}$ supplementation significantly increased hemoglobin concentrations and lowered hepcidin concentrations, improving iron metabolism and the blood's ability to transport oxygen [128].

\section{Recommendations}

\subsection{Hospital-Acquired Infections}

Hospitals are a source of RTIs for both patients and medical personnel. For example, during the SARS-CoV epidemic, a woman returned to Toronto from Hong Kong with SARS-CoV in 2003 and went to a hospital. The disease was transmitted to other people, leading to an outbreak among 257 people in several Greater Toronto Area hospitals [129]. During the 2014-2015 influenza season, 36\% of health care workers in a German hospital developed influenza infection [130].

Working in a hospital dealing with COVID-19 patients is associated with increased risk of COVID-19 infection. For example, 40 of 138 hospitalized COVID-19 patients in Wuhan in the Zhongnan Hospital from 1 to 28 January were medical staff, and 17 more were infected while in the hospital [58]. It was announced on February 14, 2020, that more than 1700 Chinese health workers were infected by COVID-19 and six had died (https://www.huffpost.com/entry/chinese-health-workers-infected-by virus_n_5e46a0fec5b64d860fc97c1b). 
Vitamin D supplementation to raise serum 25(OH)D concentrations can help reduce hospitalassociated infections [131]. Concentrations of at least 40-50 ng/mL (100-125 nmol/L) are indicated on the basis of observational studies [132,133]. During the COVID-19 epidemic, all people in the hospital, including patients and staff, should take vitamin D supplements to raise $25(\mathrm{OH}) \mathrm{D}$ concentrations as an important step in preventing infection and spread. Trials on that hypothesis would be worth conducting.

\subsection{Proposed Actions}

The data reviewed here supports the role of higher $25(\mathrm{OH}) \mathrm{D}$ concentrations in reducing risk of infection and death from ARTIs, including those from influenza, $\mathrm{CoV}$, and pneumonia. The peak season for ARTIs is generally when $25(\mathrm{OH}) \mathrm{D}$ concentrations are lowest. Thus, vitamin $\mathrm{D}_{3}$ supplementation should be started or increased several months before winter to raise $25(\mathrm{OH}) \mathrm{D}$ concentrations to the range necessary to prevent ARTIs. Studies reviewed here generally reported that $25(\mathrm{OH}) \mathrm{D}$ concentrations of 20-30 ng/mL reduced the risk of ARTIs [134]. One reason for that result may be that the studies included few participants with higher $25(\mathrm{OH}) \mathrm{D}$ concentrations. However, one observational study reported that $38 \mathrm{ng} / \mathrm{mL}$ was the appropriate concentration to reduce the risk of CAP [57]. Although the degree of protection generally increases as $25(\mathrm{OH}) \mathrm{D}$ concentration increases, the optimal range appears to be in the range of 40-60 ng/mL (100-150 nmol/l). To achieve those levels, approximately half the population could take at least 2000-5000 IU/d of vitamin $\mathrm{D}_{3}$ [135]. Various loading doses have been studied for achieving a 25(OH)D concentration of $30 \mathrm{ng} / \mathrm{mL}$. For example, one study used a weekly or fortnightly dose totaling 100,000-200,000 IU over 8 weeks (1800 or 3600 IU/d) [136]. However, to achieve $40-60 \mathrm{ng} / \mathrm{mL}$ would take higher loading doses. A trial involving Canadian breast cancer patients with bone metastases treated with bisphosphonates but without comorbid conditions reported that doses of $10,000 \mathrm{IU} / \mathrm{d}$ of vitamin $\mathrm{D}_{3}$ over a four-month period showed no adverse effects, but did unmask two cases of primary hyperparathyroidism [137]. A study involving 33 participants, including seven taking $4000 \mathrm{IU} / \mathrm{d}$ of vitamin $\mathrm{D}_{3}$ and six who took 10,000 IU/d of vitamin $\mathrm{D}_{3}$ for 8 weeks, reported that $25(\mathrm{OH}) \mathrm{D}$ concentrations increased from $20 \pm 6$ to $39 \pm 9$ for $4000 \mathrm{IU} / \mathrm{d}$ and from $19 \pm 4$ to $67 \pm 3$ for $10,000 \mathrm{IU} / \mathrm{d}$ and improved gut microbiota with no adverse effects [138]. Thus, from the literature, it is reasonable to suggest taking 10,000 IU/d for a month, which is effective in rapidly increasing circulating levels of 25(OH)D into the preferred range of $40-60 \mathrm{ng} / \mathrm{mL}$. To maintain that level after that first month, the dose can be decreased to $5000 \mathrm{IU} / \mathrm{d}[135,139,140]$. When high doses of vitamin $\mathrm{D}$ are taken, calcium supplementation should not be high to reduce risk of hypercalcemia.

A recent review suggested using vitamin D loading doses of 200,000-300,000 IU in 50,000-IU capsules to reduce the risk and severity of COVID-19 [43].

The efficacy and safety of high-dose vitamin D supplementation has been demonstrated in a psychiatric hospital in Cincinnati, Ohio [141]. The age range was from 18 to 90 years. Half of the patients were black, and nearly half were white. All patients entering since 2011 were offered supplementation of 5000 or $10,000 \mathrm{IU} / \mathrm{d}$ vitamin $\mathrm{D}_{3}$. For 36 patients who received $5000 \mathrm{IU} / \mathrm{d}$ for 12 months or longer, mean serum 25(OH)D concentration rose from 24 to $68 \mathrm{ng} / \mathrm{mL}$, whereas for the 78 patients who received 10,000 IU/d, mean concentrations increased from 25 to $96 \mathrm{ng} / \mathrm{mL}$. No cases of vitamin D-induced hypercalcemia were reported. This article includes a brief review of other high-dose vitamin D studies, including the fact that vitamin D doses of 60,000-600,000 IU/d were found to treat and control such diseases as asthma, rheumatoid arthritis, rickets, and tuberculosis in the 1930s and 1940s. Those doses are much higher than the 10,000-25,000 IU/d of vitamin $\mathrm{D}_{3}$ that can be made from solar UVB exposure [142]. However, after reports of hypercalcemia associated with use of supra-physiological doses of vitamin D surfaced, e.g., [143], high-dose vitamin D supplementation fell out of favor.

A recent article on a high-dose vitamin D supplementation trial in New Zealand involving 5110 participants reported that, over a median of 3.3 years, monthly supplementation with 100,000 IU of vitamin $\mathrm{D}_{3}$ did not affect the incidence rate of kidney stone events or hypercalcemia [144].

Unfortunately, most countries do not have guidelines supporting vitamin D supplementation doses and desirable serum 25(OH)D concentrations that would deal with wintertime RTIs. Guidelines for 
many countries consider $20 \mathrm{ng} / \mathrm{mL}$ (50 nmol/L) adequate. According to the statement from the European Society for Clinical and Economic Aspects of Osteoporosis, Osteoarthritis, and Musculoskeletal Diseases, "attainment of serum 25-hydroxyvitamin D levels well above the threshold desired for bone health cannot be recommended based on current evidence, since safety has yet to be confirmed" [145]. This statement, published in 2017, is no longer correct since a number of vitamin D supplementation studies have reported that long-term vitamin D supplementation has health benefits without adverse health effects, e.g., $2000 \mathrm{IU} / \mathrm{d}$ for cancer risk reduction [66,146] and $4000 \mathrm{IU} / \mathrm{d}$ for reduced progression from prediabetes to diabetes [67].

A recent review on the status of vitamin $\mathrm{D}$ deficiency worldwide stated that because of inadequate evidence from clinical trials, "a $25(\mathrm{OH}) \mathrm{D}$ level of $>50 \mathrm{nmol} / \mathrm{L}$ or $20 \mathrm{ng} / \mathrm{mL}$ is, therefore, the primary treatment goal, although some data suggest a benefit for a higher threshold" [147]. A companion article in the same issue of the journal stated, "although $20 \mathrm{ng} / \mathrm{mL}$ seems adequate to reduce risk of skeletal problems and ARTIs, concentrations above $30 \mathrm{ng} / \mathrm{mL}$ have been associated with reduced risk of cancer, type 2 diabetes mellitus, and adverse pregnancy and birth outcomes" [148]. However, on the basis of the findings in several studies discussed here, as well as recommendations for breast and colorectal cancer prevention [149], the desirable concentration should be at least 40-60 ng/mL.

The U.S. Institute of Medicine issued vitamin D and calcium guidelines in 2011 [150]. The institute recommended vitamin D supplementation of $600 \mathrm{IU} / \mathrm{d}$ for people younger than 70 years, $800 \mathrm{IU} / \mathrm{d}$ for those older than 70 years, and a serum 25(OH)D concentration of $20 \mathrm{ng} / \mathrm{mL}(50 \mathrm{nmol} / \mathrm{L})$ or higher. That recommendation was based on the effects of vitamin $\mathrm{D}$ for bone health. The institute recognized that no studies had reported adverse effects of supplementation with less than 10,000 IU/d of vitamin $\mathrm{D}$, but set the upper intake level at $4000 \mathrm{IU} / \mathrm{d}$, partly out of concerns stemming from observational studies that found U-shaped $25(\mathrm{OH}) \mathrm{D}$ concentration-health outcome relationships. However, later investigation determined that most reports of J- or U-shaped relationships were from observational studies that did not measure serum 25(OH)D concentrations and that the likely reason for those relationships was a result of enrolling some participants who had started taking vitamin D supplements shortly before enrolling [151].

Moreover, in 2011, the Endocrine Society recommended supplementation of 1000-4000 IU/d of vitamin D and a serum 25(OH)D concentration of $30 \mathrm{ng} / \mathrm{mL}$ or higher [152]. Those guidelines were for patients. It appears that anyone with chronic disease should be considered in that category. The U.S. Institute of Medicine noted that no adverse effects of vitamin D supplementation had been reported for daily doses <10,000 IU/d [150].

Measuring serum 25(OH)D concentration would be useful to determine baseline and achieved 25(OH)D concentrations. A recent article recommended testing for groups of people who were likely to have low concentrations and could benefit from higher concentrations, such as pregnant women, the obese, people with chronic diseases, and the elderly [148]. Part of the rationale for testing was to increase awareness of actual $25(\mathrm{OH}) \mathrm{D}$ concentrations and the benefits of higher concentrations. In addition, increases in $25(\mathrm{OH}) \mathrm{D}$ concentration with respect to vitamin $\mathrm{D}$ supplementation depend on various personal factors, including genetics, digestive system health, weight, and baseline $25(\mathrm{OH}) \mathrm{D}$ concentration. For about half the population, taking $5000 \mathrm{IU} / \mathrm{d}$ of vitamin $\mathrm{D}_{3}$ or 30,000-35,000 IU/wk would raise $25(\mathrm{OH}) \mathrm{D}$ concentration to $40 \mathrm{ng} / \mathrm{mL}$. Taking $6235-7248 \mathrm{IU} / \mathrm{d}$ as proposed to ensure that $97.5 \%$ of the population has concentrations $>20 \mathrm{ng} / \mathrm{mL}$ [153] would not exceed the 10,000-IU/d threshold.

Vitamin D supplementation is required for many individuals to reach $25(\mathrm{OH}) \mathrm{D}$ concentrations above $30 \mathrm{ng} / \mathrm{mL}$, especially in winter [154]. However, vitamin D fortification of basic foods such as dairy and flour products $[83,155]$ can raise serum $25(\mathrm{OH}) \mathrm{D}$ concentrations of those members of various populations with the lowest concentrations by a few $\mathrm{ng} / \mathrm{mL}$. Doing so can result in reduced risk of ARTIs for individuals with extreme vitamin D deficiency [134,156]. However, for greater benefits, daily or weekly vitamin D supplementation is recommended [134], as is the annual determination of serum $25(\mathrm{OH}) \mathrm{D}$ concentration for those with health risks [148]. 
Magnesium supplementation is recommended when taking vitamin D supplements. Magnesium helps activate vitamin D, which in turn helps regulate calcium and phosphate homeostasis to influence the growth and maintenance of bones. All the enzymes that metabolize vitamin D seem to require magnesium, which acts as a cofactor in the enzymatic reactions in the liver and kidneys [157]. The dose of magnesium should be in the range of $250-500 \mathrm{mg} / \mathrm{d}$, along with twice that dose of calcium.

The hypothesis that vitamin D supplementation can reduce the risk of influenza and COVID-19 incidence and death should be investigated in trials to determine the appropriate doses, serum $25(\mathrm{OH}) \mathrm{D}$ concentrations, and the presence of any safety issues. The RCT on vitamin D supplementation for ventilated ICU patients conducted in Atlanta, Georgia, is a good model [93].

A recent review stated: "Although contradictory data exist, available evidence indicates that supplementation with multiple micronutrients with immune-supporting roles may modulate immune function and reduce the risk of infection. Micronutrients with the strongest evidence for immune support are vitamins $C$ and D and zinc. Better design of human clinical studies addressing dosage and combinations of micronutrients in different populations are required to substantiate the benefits of micronutrient supplementation against infection." [17].

Author Contributions: Conceptualization, W.B.G., H.L. and C.A.B.; methodology, W.B.G., H.L., C.A.B.; writing-original draft preparation, W.B.G., C.A.B., H.P.B; writing-review and editing, W.B.G., H.L., S.L.M., C.A.B., C.B.F., J.L.A., and H.P.B.; supervision, W.B.G., C.A.B. All authors have read and agreed to the published version of the manuscript. Authorship must be limited to those who have contributed substantially to the work reported.

Funding: No funding was received for this study.

Conflicts of Interest: W.B.G receives funding from Bio-Tech Pharmacal, Inc. (Fayetteville, AR). H.L. sells vitamin D supplements. GrassrootsHealth works with various supplement suppliers to test the efficacy of their products in various custom projects. These suppliers may be listed as sponsors of GrassrootsHealth. H.P.B. has no conflicts of interest to declare.

\section{References}

1. Zhu, N.; Zhang, D.; Wang, W.; Li, X.; Yang, B.; Song, J.; Zhao, X.; Huang, B.; Shi, W.; Lu, R.; et al. A Novel Coronavirus from Patients with Pneumonia in China, 2019. N. Engl. J. Med. 2020. [CrossRef] [PubMed]

2. Zhong, N.S.; Zheng, B.J.; Li, Y.M.; Poon, L.L.M.; Xie, Z.H.; Chan, K.H.; Li, P.H.; Tan, S.Y.; Chang, Q.; Xie, J.P.; et al. Epidemiology and cause of severe acute respiratory syndrome (SARS) in Guangdong, People's Republic of China, in February, 2003. Lancet 2003, 362, 1353-1358. [CrossRef]

3. Assiri, A.; McGeer, A.; Perl, T.M.; Price, C.S.; Al Rabeeah, A.A.; Cummings, D.A.; Alabdullatif, Z.N.; Assad, M.; Almulhim, A.; Makhdoom, H.; et al. Hospital outbreak of Middle East respiratory syndrome coronavirus. N. Engl. J. Med. 2013, 369, 407-416. [CrossRef] [PubMed]

4. Song, Z.; Xu, Y.; Bao, L.; Zhang, L.; Yu, P.; Qu, Y.; Zhu, H.; Zhao, W.; Han, Y.; Qin, C. From SARS to MERS, Thrusting Coronaviruses into the Spotlight. Viruses 2019, 11, 59. [CrossRef]

5. Yin, Y.; Wunderink, R.G. MERS, SARS and other coronaviruses as causes of pneumonia. Respirology 2018, 23, 130-137. [CrossRef]

6. Paget, J.; Spreeuwenberg, P.; Charu, V.; Taylor, R.J.; Iuliano, A.D.; Bresee, J.; Simonsen, L.; Viboud, C. Global mortality associated with seasonal influenza epidemics: New burden estimates and predictors from the GLaMOR Project. J. Glob. Health 2019, 9, 020421. [CrossRef]

7. Holick, M.F. Vitamin D deficiency. N. Engl. J. Med. 2007, 357, 266-281. [CrossRef]

8. Pike, J.W.; Christakos, S. Biology and Mechanisms of Action of the Vitamin D Hormone. Endocrinol. Metab. Clin. 2017, 46, 815-843. [CrossRef]

9. Beard, J.A.; Bearden, A.; Striker, R. Vitamin D and the anti-viral state. J. Clin. Virol. 2011, 50, $194-200$. [CrossRef]

10. Hewison, M. An update on vitamin D and human immunity. Clin. Endocrinol. 2012, 76, 315-325. [CrossRef]

11. Greiller, C.L.; Martineau, A.R. Modulation of the immune response to respiratory viruses by vitamin D. Nutrients 2015, 7, 4240-4270. [CrossRef] [PubMed]

12. Wei, R.; Christakos, S. Mechanisms Underlying the Regulation of Innate and Adaptive Immunity by Vitamin D. Nutrients 2015, 7, 8251-8260. [CrossRef] [PubMed] 
13. Coussens, A.K. The role of UV radiation and vitamin D in the seasonality and outcomes of infectious disease. Photochem. Photobiol. Sci. 2017, 16, 314-338. [CrossRef]

14. Lang, P.O.; Aspinall, R. Vitamin D Status and the Host Resistance to Infections: What It Is Currently (Not) Understood. Clin. Ther. 2017, 39, 930-945. [CrossRef] [PubMed]

15. Gruber-Bzura, B.M. Vitamin D and Influenza-Prevention or Therapy? Int. J. Mol. Sci. 2018, 19, 2419. [CrossRef] [PubMed]

16. Rondanelli, M.; Miccono, A.; Lamburghini, S.; Avanzato, I.; Riva, A.; Allegrini, P.; Faliva, M.A.; Peroni, G.; Nichetti, M.; Perna, S. Self-Care for Common Colds: The Pivotal Role of Vitamin D, Vitamin C, Zinc, and Echinacea in Three Main Immune Interactive Clusters (Physical Barriers, Innate and Adaptive Immunity) Involved during an Episode of Common Colds-Practical Advice on Dosages and on the Time to Take These Nutrients/Botanicals in order to Prevent or Treat Common Colds. Evid. Based Complement. Alternat. Med. 2018, 2018, 5813095. [CrossRef]

17. Gombart, A.F.; Pierre, A.; Maggini, S. A Review of Micronutrients and the Immune System-Working in Harmony to Reduce the Risk of Infection. Nutrients 2020, 12, 236. [CrossRef]

18. Schwalfenberg, G.K. A review of the critical role of vitamin D in the functioning of the immune system and the clinical implications of vitamin D deficiency. Mol. Nutr. Food Res. 2011, 55, 96-108. [CrossRef]

19. Kast, J.I.; McFarlane, A.J.; Globinska, A.; Sokolowska, M.; Wawrzyniak, P.; Sanak, M.; Schwarze, J.; Akdis, C.A.; Wanke, K. Respiratory syncytial virus infection influences tight junction integrity. Clin. Exp. Immunol. 2017, 190, 351-359. [CrossRef]

20. Chen, Y.; Leng, K.; Lu, Y.; Wen, L.; Qi, Y.; Gao, W.; Chen, H.; Bai, L.; An, X.; Sun, B.; et al. Epidemiological features and time-series analysis of influenza incidence in urban and rural areas of Shenyang, China, 2010-2018. Epidemiol. Infect. 2020, 148, e29. [CrossRef]

21. Rossi, G.A.; Fanous, H.; Colin, A.A. Viral strategies predisposing to respiratory bacterial superinfections. Pediatr. Pulmonol. 2020. [CrossRef] [PubMed]

22. Liu, P.T.; Stenger, S.; Li, H.; Wenzel, L.; Tan, B.H.; Krutzik, S.R.; Ochoa, M.T.; Schauber, J.; Wu, K.; Meinken, C.; et al. Toll-like receptor triggering of a vitamin D-mediated human antimicrobial response. Science 2006, 311, 1770-1773. [CrossRef]

23. Adams, J.S.; Ren, S.; Liu, P.T.; Chun, R.F.; Lagishetty, V.; Gombart, A.F.; Borregaard, N.; Modlin, R.L.; Hewison, M. Vitamin d-directed rheostatic regulation of monocyte antibacterial responses. J. Immunol. 2009, 182, 4289-4295. [CrossRef] [PubMed]

24. Laaksi, I. Vitamin D and respiratory infection in adults. Proc. Nutr. Soc. 2012, 71, 90-97. [CrossRef] [PubMed]

25. Herr, C.; Shaykhiev, R.; Bals, R. The role of cathelicidin and defensins in pulmonary inflammatory diseases. Expert Opin. Biol. Ther. 2007, 7, 1449-1461. [CrossRef] [PubMed]

26. Agier, J.; Efenberger, M.; Brzezinska-Blaszczyk, E. Cathelicidin impact on inflammatory cells. Cent. Eur. J. Immunol. 2015, 40, 225-235. [CrossRef]

27. Barlow, P.G.; Svoboda, P.; Mackellar, A.; Nash, A.A.; York, I.A.; Pohl, J.; Davidson, D.J.; Donis, R.O. Antiviral activity and increased host defense against influenza infection elicited by the human cathelicidin LL-37. PLoS ONE 2011, 6, e25333. [CrossRef]

28. Zhao, Y.; Ran, Z.; Jiang, Q.; Hu, N.; Yu, B.; Zhu, L.; Shen, L.; Zhang, S.; Chen, L.; Chen, H.; et al. Vitamin D Alleviates Rotavirus Infection through a Microrna-155-5p Mediated Regulation of the TBK1/IRF3 Signaling Pathway In Vivo and In Vitro. Int. J. Mol. Sci. 2019, 20. [CrossRef]

29. Martinez-Moreno, J.; Hernandez, J.C.; Urcuqui-Inchima, S. Effect of high doses of vitamin D supplementation on dengue virus replication, Toll-like receptor expression, and cytokine profiles on dendritic cells. Mol. Cell. Biochem. 2020, 464, 169-180. [CrossRef]

30. Huang, C.; Wang, Y.; Li, X.; Ren, L.; Zhao, J.; Hu, Y.; Zhang, L.; Fan, G.; Xu, J.; Gu, X.; et al. Clinical features of patients infected with 2019 novel coronavirus in Wuhan, China. Lancet 2020. [CrossRef]

31. Sharifi, A.; Vahedi, H.; Nedjat, S.; Rafiei, H.; Hosseinzadeh-Attar, M.J. Effect of single-dose injection of vitamin D on immune cytokines in ulcerative colitis patients: A randomized placebo-controlled trial. APMIS 2019, 127, 681-687. [CrossRef] [PubMed]

32. Cantorna, M.T. Mechanisms underlying the effect of vitamin D on the immune system. Proc. Nutr. Soc. 2010, 69, 286-289. [CrossRef] [PubMed] 
33. Lemire, J.M.; Adams, J.S.; Kermani-Arab, V.; Bakke, A.C.; Sakai, R.; Jordan, S.C. 1,25-Dihydroxyvitamin D3 suppresses human T helper/inducer lymphocyte activity in vitro. J. Immunol. 1985, 134, 3032-3035. [PubMed]

34. Cantorna, M.T.; Snyder, L.; Lin, Y.D.; Yang, L. Vitamin D and 1,25(OH)2D regulation of T cells. Nutrients 2015, 7, 3011-3021. [CrossRef] [PubMed]

35. Jeffery, L.E.; Burke, F.; Mura, M.; Zheng, Y.; Qureshi, O.S.; Hewison, M.; Walker, L.S.; Lammas, D.A.; Raza, K.; Sansom, D.M. 1,25-Dihydroxyvitamin D3 and IL-2 combine to inhibit T cell production of inflammatory cytokines and promote development of regulatory T cells expressing CTLA-4 and FoxP3. J. Immunol. 2009, 183, 5458-5467. [CrossRef] [PubMed]

36. Vasarhelyi, B.; Satori, A.; Olajos, F.; Szabo, A.; Beko, G. Low vitamin D levels among patients at Semmelweis University: Retrospective analysis during a one-year period. Orv. Hetil. 2011, 152, 1272-1277. [CrossRef] [PubMed]

37. Novel, C.P.E.R.E. The epidemiological characteristics of an outbreak of 2019 novel coronavirus diseases (COVID-19) in China. Zhonghua Liu Xing Bing Xue Za Zhi 2020, 41, 145-151. [CrossRef]

38. MacLaughlin, J.; Holick, M.F. Aging decreases the capacity of human skin to produce vitamin D3. J. Clin. Invest. 1985, 76, 1536-1538. [CrossRef]

39. Grober, U.; Kisters, K. Influence of drugs on vitamin D and calcium metabolism. Dermatoendocrinol 2012, 4, 158-166. [CrossRef]

40. Lei, G.S.; Zhang, C.; Cheng, B.H.; Lee, C.H. Mechanisms of Action of Vitamin D as Supplemental Therapy for Pneumocystis Pneumonia. Antimicrob. Agents Chemother. 2017, 61. [CrossRef]

41. Mousavi, S.; Bereswill, S.; Heimesaat, M.M. Immunomodulatory and Antimicrobial Effects of Vitamin C. Eur. J. Microbiol. Immunol. 2019, 9, 73-79. [CrossRef] [PubMed]

42. Colunga Biancatelli, R.M.L.; Berrill, M.; Marik, P.E. The antiviral properties of vitamin C. Expert Rev. Anti Infect. Ther. 2020, 18, 99-101. [CrossRef] [PubMed]

43. Wimalawansa, S.J. Global epidemic of coronavirus-COVID-19: What we can do to minimze risksl. Eur. J. Biomed. Pharm. Sci. 2020, 7, 432-438.

44. Kalil, A.C.; Thomas, P.G. Influenza virus-related critical illness: Pathophysiology and epidemiology. Crit. Care 2019, 23, 258. [CrossRef]

45. Hope-Simpson, R.E. The role of season in the epidemiology of influenza. J. Hyg. 1981, 86, 35-47. [CrossRef]

46. Cannell, J.J.; Vieth, R.; Umhau, J.C.; Holick, M.F.; Grant, W.B.; Madronich, S.; Garland, C.F.; Giovannucci, E. Epidemic influenza and vitamin D. Epidemiol. Infect. 2006, 134, 1129-1140. [CrossRef]

47. Cannell, J.J.; Zasloff, M.; Garland, C.F.; Scragg, R.; Giovannucci, E. On the epidemiology of influenza. Virol. J. 2008, 5, 29. [CrossRef]

48. Kroll, M.H.; Bi, C.; Garber, C.C.; Kaufman, H.W.; Liu, D.; Caston-Balderrama, A.; Zhang, K.; Clarke, N.; Xie, M.; Reitz, R.E.; et al. Temporal relationship between vitamin D status and parathyroid hormone in the United States. PLoS ONE 2015, 10, e0118108. [CrossRef]

49. Lowen, A.C.; Mubareka, S.; Steel, J.; Palese, P. Influenza virus transmission is dependent on relative humidity and temperature. PLoS Pathog. 2007, 3, 1470-1476. [CrossRef]

50. Shaman, J.; Kohn, M. Absolute humidity modulates influenza survival, transmission, and seasonality. Proc. Natl. Acad. Sci. USA 2009, 106, 3243-3248. [CrossRef]

51. Shaman, J.; Pitzer, V.E.; Viboud, C.; Grenfell, B.T.; Lipsitch, M. Absolute humidity and the seasonal onset of influenza in the continental United States. PLoS Biol. 2010, 8, e1000316. [CrossRef]

52. Urashima, M.; Segawa, T.; Okazaki, M.; Kurihara, M.; Wada, Y.; Ida, H. Randomized trial of vitamin D supplementation to prevent seasonal influenza A in schoolchildren. Am. J. Clin. Nutr. 2010, 91, 1255-1260. [CrossRef] [PubMed]

53. Zhou, J.; Du, J.; Huang, L.; Wang, Y.; Shi, Y.; Lin, H. Preventive Effects of Vitamin D on Seasonal Influenza A in Infants: A Multicenter, Randomized, Open, Controlled Clinical Trial. Pediatr. Infect. Dis. J. 2018, 37, 749-754. [CrossRef] [PubMed]

54. Urashima, M.; Mezawa, H.; Noya, M.; Camargo, C.A., Jr. Effects of vitamin D supplements on influenza A illness during the 2009 H1N1 pandemic: A randomized controlled trial. Food Funct. 2014, 5, 2365-2370. [CrossRef] [PubMed] 
55. Arihiro, S.; Nakashima, A.; Matsuoka, M.; Suto, S.; Uchiyama, K.; Kato, T.; Mitobe, J.; Komoike, N.; Itagaki, M.; Miyakawa, Y.; et al. Randomized Trial of Vitamin D Supplementation to Prevent Seasonal Influenza and Upper Respiratory Infection in Patients With Inflammatory Bowel Disease. Inflamm. Bowel Dis. 2019, 25, 1088-1095. [CrossRef] [PubMed]

56. Loeb, M.; Dang, A.D.; Thiem, V.D.; Thanabalan, V.; Wang, B.; Nguyen, N.B.; Tran, H.T.M.; Luong, T.M.; Singh, P.; Smieja, M.; et al. Effect of Vitamin D supplementation to reduce respiratory infections in children and adolescents in Vietnam: A randomized controlled trial. Influenza Other Respir. Viruses 2019, 13, 176-183. [CrossRef] [PubMed]

57. Sabetta, J.R.; DePetrillo, P.; Cipriani, R.J.; Smardin, J.; Burns, L.A.; Landry, M.L. Serum 25-hydroxyvitamin $\mathrm{d}$ and the incidence of acute viral respiratory tract infections in healthy adults. PLOS ONE 2010, 5, e11088. [CrossRef]

58. Wang, D.; Hu, B.; Hu, C.; Zhu, F.; Liu, X.; Zhang, J.; Wang, B.; Xiang, H.; Cheng, Z.; Xiong, Y.; et al. Clinical Characteristics of 138 Hospitalized Patients With 2019 Novel Coronavirus-Infected Pneumonia in Wuhan, China. JAMA 2020. [CrossRef]

59. Zhou, F.; Yu, T.; Du, R.; Fan, G.; Liu, Y.; Liu, Z.; Xiang, J.; Wang, Y.; Song, B.; Gu, X.; et al. Clinical course and risk factors for mortality of adult inpatients with COVID-19 in Wuhan, China: A retrospective cohort study. Lancet 2020. [CrossRef]

60. He, Q.; Gu, Y.; Zhang, M. Spatiotemporal trends of PM2.5 concentrations in central China from 2003 to 2018 based on MAIAC-derived high-resolution data. Environ. Int. 2020, 137, 105536. [CrossRef]

61. Longhin, E.; Holme, J.A.; Gualtieri, M.; Camatini, M.; Ovrevik, J. Milan winter fine particulate matter (wPM2.5) induces IL-6 and IL-8 synthesis in human bronchial BEAS-2B cells, but specifically impairs IL-8 release. Toxicol. In Vitro 2018, 52, 365-373. [CrossRef] [PubMed]

62. Autier, P.; Mullie, P.; Macacu, A.; Dragomir, M.; Boniol, M.; Coppens, K.; Pizot, C.; Boniol, M. Effect of vitamin D supplementation on non-skeletal disorders: A systematic review of meta-analyses and randomised trials. Lancet Diabetes Endocrinol. 2017, 5, 986-1004. [CrossRef]

63. Rejnmark, L.; Bislev, L.S.; Cashman, K.D.; Eiriksdottir, G.; Gaksch, M.; Grubler, M.; Grimnes, G.; Gudnason, V.; Lips, P.; Pilz, S.; et al. Non-skeletal health effects of vitamin D supplementation: A systematic review on findings from meta-analyses summarizing trial data. PLoS ONE 2017, 12, e0180512. [CrossRef] [PubMed]

64. Heaney, R.P. Guidelines for optimizing design and analysis of clinical studies of nutrient effects. Nutr. Rev. 2014, 72, 48-54. [CrossRef] [PubMed]

65. Grant, W.B.; Boucher, B.J.; Bhattoa, H.P.; Lahore, H. Why vitamin D clinical trials should be based on 25-hydroxyvitamin D concentrations. J. Steroid Biochem. Mol. Biol. 2018, 177, 266-269. [CrossRef]

66. Manson, J.E.; Cook, N.R.; Lee, I.M.; Christen, W.; Bassuk, S.S.; Mora, S.; Gibson, H.; Gordon, D.; Copeland, T.; D'Agostino, D.; et al. Vitamin D Supplements and Prevention of Cancer and Cardiovascular Disease. N. Engl. J. Med. 2019, 380, 33-44. [CrossRef]

67. Pittas, A.G.; Dawson-Hughes, B.; Sheehan, P.; Ware, J.H.; Knowler, W.C.; Aroda, V.R.; Brodsky, I.; Ceglia, L.; Chadha, C.; Chatterjee, R.; et al. Vitamin D Supplementation and Prevention of Type 2 Diabetes. N. Engl. J. Med. 2019, 381, 520-530. [CrossRef]

68. Lu, D.; Zhang, J.; Ma, C.; Yue, Y.; Zou, Z.; Yu, C.; Yin, F. Link between community-acquired pneumonia and vitamin D levels in older patients. Z. Gerontol. Geriatr. 2018, 51, 435-439. [CrossRef]

69. Zhou, Y.F.; Luo, B.A.; Qin, L.L. The association between vitamin D deficiency and community-acquired pneumonia: A meta-analysis of observational studies. Medicine 2019, 98, e17252. [CrossRef]

70. Manion, M.; Hullsiek, K.H.; Wilson, E.M.P.; Rhame, F.; Kojic, E.; Gibson, D.; Hammer, J.; Patel, P.; Brooks, J.T.; Baker, J.V.; et al. Vitamin D deficiency is associated with IL-6 levels and monocyte activation in HIV-infected persons. PLoS ONE 2017, 12, e0175517. [CrossRef]

71. Dalvi, S.M.; Ramraje, N.N.; Patil, V.W.; Hegde, R.; Yeram, N. Study of IL-6 and vitamin D3 in patients of pulmonary tuberculosis. Indian J. Tuberc. 2019, 66, 337-345. [CrossRef] [PubMed]

72. Poudel-Tandukar, K.; Poudel, K.C.; Jimba, M.; Kobayashi, J.; Johnson, C.A.; Palmer, P.H. Serum 25-hydroxyvitamin d levels and C-reactive protein in persons with human immunodeficiency virus infection. AIDS Res. Hum. Retrovir. 2013, 29, 528-534. [CrossRef] [PubMed]

73. Zhang, M.; Gao, Y.; Tian, L.; Zheng, L.; Wang, X.; Liu, W.; Zhang, Y.; Huang, G. Association of serum 25-hydroxyvitamin D3 with adipokines and inflammatory marker in persons with prediabetes mellitus. Clin. Chim. Acta 2017, 468, 152-158. [CrossRef] [PubMed] 
74. Zhou, W.; Mao, S.; Wu, L.; Yu, J. Association Between Vitamin D Status and Sepsis. Clin. Lab. 2018, 64, 451-460. [CrossRef] [PubMed]

75. Li, Y.; Ding, S. Serum 25-Hydroxyvitamin D and the risk of mortality in adult patients with Sepsis: A meta-analysis. BMC Infect. Dis. 2020, 20, 189. [CrossRef] [PubMed]

76. Thickett, D.R.; Moromizato, T.; Litonjua, A.A.; Amrein, K.; Quraishi, S.A.; Lee-Sarwar, K.A.; Mogensen, K.M.; Purtle, S.W.; Gibbons, F.K.; Camargo, C.A., Jr.; et al. Association between prehospital vitamin D status and incident acute respiratory failure in critically ill patients: A retrospective cohort study. BMJ Open Respir. Res. 2015, 2, e000074. [CrossRef]

77. Dancer, R.C.; Parekh, D.; Lax, S.; D'Souza, V.; Zheng, S.; Bassford, C.R.; Park, D.; Bartis, D.G.; Mahida, R.; Turner, A.M.; et al. Vitamin D deficiency contributes directly to the acute respiratory distress syndrome (ARDS). Thorax 2015, 70, 617-624. [CrossRef]

78. Hou, Y.M.; Zhao, J.Y.; Liu, H.Y. Impact of serum 25-hydroxyvitamin D on cardiac prognosis in Chinese patients with heart failure. Br. J. Nutr. 2019, 122, 162-171. [CrossRef]

79. Aparicio-Ugarriza, R.; Salguero, D.; Mohammed, Y.N.; Ferri-Guerra, J.; Baskaran, D.J.; Mirabbasi, S.A.; Rodriguez, A.; Ruiz, J.G. Is vitamin D deficiency related to a higher risk of hospitalization and mortality in veterans with heart failure? Maturitas 2020, 132, 30-34. [CrossRef]

80. McDonnell, S.L.; Baggerly, L.L.; French, C.B.; Heaney, R.P.; Gorham, E.D.; Holick, M.F.; Scragg, R.; Garland, C.F. Incidence rate of type 2 diabetes is $>50 \%$ lower in GrassrootsHealth cohort with median serum 25-hydroxyvitamin D of $41 \mathrm{ng} / \mathrm{mL}$ than in NHANES cohort with median of $22 \mathrm{ng} / \mathrm{mL}$. J. Steroid Biochem. Mol. Biol. 2016, 155, 239-244. [CrossRef]

81. Xie, Z.; Xia, W.; Zhang, Z.; Wu, W.; Lu, C.; Tao, S.; Wu, L.; Gu, J.; Chandler, J.; Peter, S.; et al. Prevalence of Vitamin D Inadequacy Among Chinese Postmenopausal Women: A Nationwide, Multicenter, Cross-Sectional Study. Front. Endocrinol. 2019, 9, 782. [CrossRef] [PubMed]

82. Brot, C.; Jorgensen, N.R.; Sorensen, O.H. The influence of smoking on vitamin D status and calcium metabolism. Eur. J. Clin. Nutr. 1999, 53, 920-926. [CrossRef]

83. Pilz, S.; Marz, W.; Cashman, K.D.; Kiely, M.E.; Whiting, S.J.; Holick, M.F.; Grant, W.B.; Pludowski, P.; Hiligsmann, M.; Trummer, C.; et al. Rationale and Plan for Vitamin D Food Fortification: A Review and Guidance Paper. Front. Endocrinol. 2018, 9, 373. [CrossRef] [PubMed]

84. Chen, X.; Wu, W.; Wang, L.; Shi, Y.; Shen, F.; Gu, X.; Jia, Z. Association Between 25-Hydroxyvitamin D and Epicardial Adipose Tissue in Chinese Non-Obese Patients with Type 2 Diabetes. Med. Sci. Monit. 2017, 23, 4304-4311. [CrossRef] [PubMed]

85. Lucato, P.; Solmi, M.; Maggi, S.; Bertocco, A.; Bano, G.; Trevisan, C.; Manzato, E.; Sergi, G.; Schofield, P.; Kouidrat, Y.; et al. Low vitamin D levels increase the risk of type 2 diabetes in older adults: A systematic review and meta-analysis. Maturitas 2017, 100, 8-15. [CrossRef]

86. Qi, D.; Nie, X.L.; Wu, S.; Cai, J. Vitamin D and hypertension: Prospective study and meta-analysis. PLoS ONE 2017, 12, e0174298. [CrossRef]

87. Gholami, F.; Moradi, G.; Zareei, B.; Rasouli, M.A.; Nikkhoo, B.; Roshani, D.; Ghaderi, E. The association between circulating 25-hydroxyvitamin D and cardiovascular diseases: A meta-analysis of prospective cohort studies. BMC Cardiovasc. Disord. 2019, 19, 248. [CrossRef]

88. Zhu, M.; Wang, T.; Wang, C.; Ji, Y. The association between vitamin D and COPD risk, severity, and exacerbation: An updated systematic review and meta-analysis. Int. J. Chron. Obstruct. Pulmon. Dis. 2016, 11, 2597-2607. [CrossRef]

89. Hoseinzadeh, E.; Taha, P.; Wei, C.; Godini, H.; Ashraf, G.M.; Taghavi, M.; Miri, M. The impact of air pollutants, UV exposure and geographic location on vitamin D deficiency. Food Chem. Toxicol. 2018, 113, 241-254. [CrossRef]

90. Slow, S.; Epton, M.; Storer, M.; Thiessen, R.; Lim, S.; Wong, J.; Chin, P.; Tovaranonte, P.; Pearson, J.; Chambers, S.T.; et al. Effect of adjunctive single high-dose vitamin D3 on outcome of community-acquired pneumonia in hospitalised adults: The VIDCAPS randomised controlled trial. Sci. Rep. 2018, 8, 13829. [CrossRef]

91. Mirzavandi, F.; Talenezhad, N.; Razmpoosh, E.; Nadjarzadeh, A.; Mozaffari-Khosravi, H. The effect of intramuscular megadose of vitamin D injections on E-selectin, CRP and biochemical parameters in vitamin D-deficient patients with type-2 diabetes mellitus: A randomized controlled trial. Complement. Ther. Med. 2020, 49, 102346. [CrossRef] [PubMed] 
92. Amrein, K.; Papinutti, A.; Mathew, E.; Vila, G.; Parekh, D. Vitamin D and critical illness: What endocrinology can learn from intensive care and vice versa. Endocr. Connect. 2018, 7, R304-R315. [CrossRef] [PubMed]

93. Han, J.E.; Jones, J.L.; Tangpricha, V.; Brown, M.A.; Brown, L.A.S.; Hao, L.; Hebbar, G.; Lee, M.J.; Liu, S.; Ziegler, T.R.; et al. High Dose Vitamin D Administration in Ventilated Intensive Care Unit Patients: A Pilot Double Blind Randomized Controlled Trial. J. Clin. Transl. Endocrinol. 2016, 4, 59-65. [CrossRef] [PubMed]

94. Cho, N.H.; Shaw, J.E.; Karuranga, S.; Huang, Y.; da Rocha Fernandes, J.D.; Ohlrogge, A.W.; Malanda, B. IDF Diabetes Atlas: Global estimates of diabetes prevalence for 2017 and projections for 2045. Diabetes Res. Clin. Pract. 2018, 138, 271-281. [CrossRef]

95. Henley, S.J.; Gallaway, S.; Singh, S.D.; O’Neil, M.E.; Buchanan Lunsford, N.; Momin, B.; Richards, T.B. Lung Cancer Among Women in the United States. J. Womens Health 2018, 27, 1307-1316. [CrossRef]

96. Malinovschi, A.; Masoero, M.; Bellocchia, M.; Ciuffreda, A.; Solidoro, P.; Mattei, A.; Mercante, L.; Heffler, E.; Rolla, G.; Bucca, C. Severe vitamin D deficiency is associated with frequent exacerbations and hospitalization in COPD patients. Respir. Res. 2014, 15, 131. [CrossRef]

97. Kim, H.J.; Jang, J.G.; Hong, K.S.; Park, J.K.; Choi, E.Y. Relationship between serum vitamin D concentrations and clinical outcome of community-acquired pneumonia. Int. J. Tuberc. Lung Dis. 2015, 19, 729-734. [CrossRef]

98. Naghshtabrizi, B.; Borzouei, S.; Bigvand, P.; Seifrabiei, M.A. Evaluation of the Relationship between Serum 25-Hydroxy Vitamin D and Hypertension in Hamadan, Iran-A Case Control Study. J. Clin. Diagn. Res. 2017, 11, LC01-LC03. [CrossRef]

99. Valcour, A.; Blocki, F.; Hawkins, D.M.; Rao, S.D. Effects of age and serum 25-OH-vitamin D on serum parathyroid hormone levels. J. Clin. Endocrinol. Metab. 2012, 97, 3989-3995. [CrossRef]

100. Christensen, M.H.; Lien, E.A.; Hustad, S.; Almas, B. Seasonal and age-related differences in serum 25-hydroxyvitamin D, 1,25-dihydroxyvitamin D and parathyroid hormone in patients from Western Norway. Scand. J. Clin. Lab. Invest. 2010, 70, 281-286. [CrossRef]

101. Nam, H.H.; Ison, M.G. Respiratory syncytial virus infection in adults. BMJ 2019, 366, 15021. [CrossRef] [PubMed]

102. Paynter, S.; Ware, R.S.; Sly, P.D.; Weinstein, P.; Williams, G. Respiratory syncytial virus seasonality in tropical Australia. Aust. N. Z. J. Public Health 2015, 39, 8-10. [CrossRef] [PubMed]

103. Feng, X.; Guo, T.; Wang, Y.; Kang, D.; Che, X.; Zhang, H.; Cao, W.; Wang, P. The vitamin D status and its effects on life quality among the elderly in Jinan, China. Arch. Gerontol. Geriatr. 2016, 62, 26-29. [CrossRef] [PubMed]

104. Nassar, M.S.; Bakhrebah, M.A.; Meo, S.A.; Alsuabeyl, M.S.; Zaher, W.A. Global seasonal occurrence of middle east respiratory syndrome coronavirus (MERS-CoV) infection. Eur. Rev. Med. Pharmacol. Sci. 2018, 22, 3913-3918. [CrossRef] [PubMed]

105. Grant, W.B.; Fakhoury, H.M.A.; Karras, S.N.; Al Anouti, F.; Bhattoa, H.P. Variations in 25-Hydroxyvitamin D in Countries from the Middle East and Europe: The Roles of UVB Exposure and Diet. Nutrients 2019, 11, 2065. [CrossRef] [PubMed]

106. Moura, F.E.; Perdigao, A.C.; Siqueira, M.M. Seasonality of influenza in the tropics: A distinct pattern in northeastern Brazil. Am. J. Trop. Med. Hyg. 2009, 81, 180-183. [CrossRef] [PubMed]

107. Arboleda, J.F.; Urcuqui-Inchima, S. Vitamin D-Regulated MicroRNAs: Are They Protective Factors against Dengue Virus Infection? Adv. Virol. 2016, 2016, 1016840. [CrossRef]

108. Villamor, E.; Villar, L.A.; Lozano, A.; Herrera, V.M.; Herran, O.F. Vitamin D serostatus and dengue fever progression to dengue hemorrhagic fever/dengue shock syndrome. Epidemiol. Infect. 2017, 145, 2961-2970. [CrossRef]

109. Fan, H.Z.; Zhang, R.; Tian, T.; Zhong, Y.L.; Wu, M.P.; Xie, C.N.; Yang, J.J.; Huang, P.; Yu, R.B.; Zhang, Y.; et al. CYP24A1 genetic variants in the vitamin D metabolic pathway are involved in the outcomes of hepatitis C virus infection among high-risk Chinese population. Int. J. Infect. Dis. 2019, 84, 80-88. [CrossRef]

110. Hu, Y.C.; Wang, W.W.; Jiang, W.Y.; Li, C.Q.; Guo, J.C.; Xun, Y.H. Low vitamin D levels are associated with high viral loads in patients with chronic hepatitis B: A systematic review and meta-analysis. BMC Gastroenterol. 2019, 19, 84. [CrossRef]

111. Brice, D.C.; Toth, Z.; Diamond, G. LL-37 disrupts the Kaposi's sarcoma-associated herpesvirus envelope and inhibits infection in oral epithelial cells. Antivir. Res. 2018, 158, 25-33. [CrossRef] [PubMed] 
112. Alvarez, N.; Aguilar-Jimenez, W.; Rugeles, M.T. The Potential Protective Role of Vitamin D Supplementation on HIV-1 Infection. Front. Immunol. 2019, 10, 2291. [CrossRef] [PubMed]

113. Gui, B.; Chen, Q.; Hu, C.; Zhu, C.; He, G. Effects of calcitriol (1, 25-dihydroxy-vitamin D3) on the inflammatory response induced by H9N2 influenza virus infection in human lung A549 epithelial cells and in mice. Virol. J. 2017, 14, 10. [CrossRef] [PubMed]

114. Currie, S.M.; Findlay, E.G.; McHugh, B.J.; Mackellar, A.; Man, T.; Macmillan, D.; Wang, H.; Fitch, P.M.; Schwarze, J.; Davidson, D.J. The human cathelicidin LL-37 has antiviral activity against respiratory syncytial virus. PLOS ONE 2013, 8, e73659. [CrossRef]

115. Laplana, M.; Royo, J.L.; Fibla, J. Vitamin D Receptor polymorphisms and risk of enveloped virus infection: A meta-analysis. Gene 2018, 678, 384-394. [CrossRef]

116. Bucak, I.H.; Ozturk, A.B.; Almis, H.; Cevik, M.O.; Tekin, M.; Konca, C.; Turgut, M.; Bulbul, M. Is there a relationship between low vitamin D and rotaviral diarrhea? Pediatr. Int. 2016, 58, 270-273. [CrossRef]

117. Theron, M.; Huang, K.J.; Chen, Y.W.; Liu, C.C.; Lei, H.Y. A probable role for IFN-gamma in the development of a lung immunopathology in SARS. Cytokine 2005, 32, 30-38. [CrossRef]

118. Wong, C.K.; Lam, C.W.; Wu, A.K.; Ip, W.K.; Lee, N.L.; Chan, I.H.; Lit, L.C.; Hui, D.S.; Chan, M.H.; Chung, S.S.; et al. Plasma inflammatory cytokines and chemokines in severe acute respiratory syndrome. Clin. Exp. Immunol. 2004, 136, 95-103. [CrossRef]

119. Mahallawi, W.H.; Khabour, O.F.; Zhang, Q.; Makhdoum, H.M.; Suliman, B.A. MERS-CoV infection in humans is associated with a pro-inflammatory Th1 and Th17 cytokine profile. Cytokine 2018, 104, 8-13. [CrossRef]

120. Britten, R. The incidence of epidemic influenza, 1918-19. Public Health Rep. 1932, 47, 303-339. [CrossRef]

121. Grant, W.B.; Giovannucci, E. The possible roles of solar ultraviolet-B radiation and vitamin D in reducing case-fatality rates from the 1918-1919 influenza pandemic in the United States. Dermatoendocrinol 2009, 1, 215-219. [CrossRef] [PubMed]

122. Feigenbaum, J.J.; Muller, C.; Wrigley-Field, E. Regional and Racial Inequality in Infectious Disease Mortality in U.S. Cities, 1900-1948. Demography 2019, 56, 1371-1388. [CrossRef] [PubMed]

123. Aloia, J.F.; Li-Ng, M. Re: Epidemic influenza and vitamin D. Epidemiol. Infect. 2007, 135, 1095-1096, author reply 1097-1098. [CrossRef] [PubMed]

124. Ginde, A.A.; Liu, M.C.; Camargo, C.A., Jr. Demographic differences and trends of vitamin D insufficiency in the US population, 1988-2004. Arch. Intern. Med. 2009, 169, 626-632. [CrossRef]

125. Clay, K.; Lewis, J.; Severnini, E. What explains cross-city variation in mortality during the 1918 influenza pandemic? Evidence from 438 U.S. cities. Econ. Hum. Biol. 2019, 35, 42-50. [CrossRef] [PubMed]

126. Liu, X.X.; Li, Y.; Qin, G.; Zhu, Y.; Li, X.; Zhang, J.; Zhao, K.; Hu, M.; Wang, X.L.; Zheng, X. Effects of air pollutants on occurrences of influenza-like illness and laboratory-confirmed influenza in Hefei, China. Int. J. Biometeorol. 2019, 63, 51-60. [CrossRef]

127. Croft, D.P.; Zhang, W.; Lin, S.; Thurston, S.W.; Hopke, P.K.; van Wijngaarden, E.; Squizzato, S.; Masiol, M.; Utell, M.J.; Rich, D.Q. Associations between Source-Specific Particulate Matter and Respiratory Infections in New York State Adults. Environ. Sci. Technol. 2020, 54, 975-984. [CrossRef]

128. Smith, E.M.; Jones, J.L.; Han, J.E.; Alvarez, J.A.; Sloan, J.H.; Konrad, R.J.; Zughaier, S.M.; Martin, G.S.; Ziegler, T.R.; Tangpricha, V. High-Dose Vitamin D3 Administration Is Associated With Increases in Hemoglobin Concentrations in Mechanically Ventilated Critically Ill Adults: A Pilot Double-Blind, Randomized, Placebo-Controlled Trial. JPEN J. Parenter. Enter. Nutr. 2018, 42, 87-94. [CrossRef]

129. Centers for Disease Control and Prevention. Update: Severe acute respiratory syndrome-Toronto, Canada, 2003. MMWR Morb. Mortal. Wkly. Rep. 2003, 52, 547-550.

130. Hagel, S.; Ludewig, K.; Moeser, A.; Baier, M.; Loffler, B.; Schleenvoigt, B.; Forstner, C.; Pletz, M.W. Characteristics and management of patients with influenza in a German hospital during the 2014/2015 influenza season. Infection 2016, 44, 667-672. [CrossRef]

131. Youssef, D.A.; Ranasinghe, T.; Grant, W.B.; Peiris, A.N. Vitamin D's potential to reduce the risk of hospital-acquired infections. Derm. Endocrinol. 2012, 4, 167-175. [CrossRef] [PubMed]

132. Quraishi, S.A.; Bittner, E.A.; Blum, L.; Hutter, M.M.; Camargo, C.A., Jr. Association between preoperative 25-hydroxyvitamin $\mathrm{D}$ level and hospital-acquired infections following Roux-en-Y gastric bypass surgery. JAMA Surg. 2014, 149, 112-118. [CrossRef] [PubMed] 
133. Laviano, E.; Sanchez Rubio, M.; Gonzalez-Nicolas, M.T.; Palacian, M.P.; Lopez, J.; Gilaberte, Y.; Calmarza, P.; Rezusta, A.; Serrablo, A. Association between preoperative levels of 25-hydroxyvitamin $\mathrm{D}$ and hospital-acquired infections after hepatobiliary surgery: A prospective study in a third-level hospital. PLoS ONE 2020, 15, e0230336. [CrossRef] [PubMed]

134. Martineau, A.R.; Jolliffe, D.A.; Hooper, R.L.; Greenberg, L.; Aloia, J.F.; Bergman, P.; Dubnov-Raz, G.; Esposito, S.; Ganmaa, D.; Ginde, A.A.; et al. Vitamin D supplementation to prevent acute respiratory tract infections: Systematic review and meta-analysis of individual participant data. BMJ 2017, 356, i6583. [CrossRef] [PubMed]

135. Heaney, R.P.; Davies, K.M.; Chen, T.C.; Holick, M.F.; Barger-Lux, M.J. Human serum 25-hydroxycholecalciferol response to extended oral dosing with cholecalciferol. Am. J. Clin. Nutr. 2003, 77, 204-210. [CrossRef] [PubMed]

136. van Groningen, L.; Opdenoordt, S.; van Sorge, A.; Telting, D.; Giesen, A.; de Boer, H. Cholecalciferol loading dose guideline for vitamin D-deficient adults. Eur. J. Endocrinol. 2010, 162, 805-811. [CrossRef]

137. Amir, E.; Simmons, C.E.; Freedman, O.C.; Dranitsaris, G.; Cole, D.E.; Vieth, R.; Ooi, W.S.; Clemons, M. A phase 2 trial exploring the effects of high-dose (10,000 IU/day) vitamin $\mathrm{D}(3)$ in breast cancer patients with bone metastases. Cancer 2010, 116, 284-291. [CrossRef]

138. Charoenngam, N.; Shirvani, A.; Kalajian, T.A.; Song, A.; Holick, M.F. The Effect of Various Doses of Oral Vitamin D3 Supplementation on Gut Microbiota in Healthy Adults: A Randomized, Double-blinded, Dose-response Study. Anticancer Res. 2020, 40, 551-556. [CrossRef]

139. Ekwaru, J.P.; Zwicker, J.D.; Holick, M.F.; Giovannucci, E.; Veugelers, P.J. The importance of body weight for the dose response relationship of oral vitamin D supplementation and serum 25-hydroxyvitamin D in healthy volunteers. PLoS ONE 2014, 9, e111265. [CrossRef]

140. Shirvani, A.; Kalajian, T.A.; Song, A.; Holick, M.F. Disassociation of Vitamin D's Calcemic Activity and Non-calcemic Genomic Activity and Individual Responsiveness: A Randomized Controlled Double-Blind Clinical Trial. Sci. Rep. 2019, 9, 17685. [CrossRef]

141. McCullough, P.J.; Lehrer, D.S.; Amend, J. Daily oral dosing of vitamin D3 using 5000 TO 50,000 international units a day in long-term hospitalized patients: Insights from a seven year experience. J. Steroid Biochem. Mol. Biol. 2019, 189, 228-239. [CrossRef] [PubMed]

142. Holick, M.F. Environmental factors that influence the cutaneous production of vitamin D. Am. J. Clin. Nutr. 1995, 61, 638S-645S. [CrossRef] [PubMed]

143. Howard, J.E.; Meyer, R.J. Intoxication with vitamin D. J. Clin. Endocrinol. Metab. 1948, 8, 895-910. [CrossRef] [PubMed]

144. Malihi, Z.; Lawes, C.M.M.; Wu, Z.; Huang, Y.; Waayer, D.; Toop, L.; Khaw, K.T.; Camargo, C.A.; Scragg, R. Monthly high-dose vitamin $\mathrm{D}$ supplementation does not increase kidney stone risk or serum calcium: Results from a randomized controlled trial. Am. J. Clin. Nutr. 2019, 109, 1578-1587. [CrossRef]

145. Cianferotti, L.; Bertoldo, F.; Bischoff-Ferrari, H.A.; Bruyere, O.; Cooper, C.; Cutolo, M.; Kanis, J.A.; Kaufman, J.M.; Reginster, J.Y.; Rizzoli, R.; et al. Vitamin D supplementation in the prevention and management of major chronic diseases not related to mineral homeostasis in adults: Research for evidence and a scientific statement from the European society for clinical and economic aspects of osteoporosis and osteoarthritis (ESCEO). Endocrine 2017, 56, 245-261. [CrossRef]

146. Lappe, J.; Watson, P.; Travers-Gustafson, D.; Recker, R.; Garland, C.; Gorham, E.; Baggerly, K.; McDonnell, S.L. Effect of Vitamin D and Calcium Supplementation on Cancer Incidence in Older Women: A Randomized Clinical Trial. JAMA 2017, 317, 1234-1243. [CrossRef]

147. Amrein, K.; Scherkl, M.; Hoffmann, M.; Neuwersch-Sommeregger, S.; Kostenberger, M.; Tmava Berisha, A.; Martucci, G.; Pilz, S.; Malle, O. Vitamin D deficiency 2.0: An update on the current status worldwide. Eur. J. Clin. Nutr. 2020. [CrossRef]

148. Grant, W.B.; Al Anouti, F.; Moukayed, M. Targeted 25-hydroxyvitamin D concentration measurements and vitamin D3 supplementation can have important patient and public health benefits. Eur. J. Clin. Nutr. 2020. [CrossRef]

149. Garland, C.F.; Gorham, E.D.; Mohr, S.B.; Garland, F.C. Vitamin D for cancer prevention: Global perspective. Ann. Epidemiol. 2009, 19, 468-483. [CrossRef] 
150. Ross, A.C.; Manson, J.E.; Abrams, S.A.; Aloia, J.F.; Brannon, P.M.; Clinton, S.K.; Durazo-Arvizu, R.A.; Gallagher, J.C.; Gallo, R.L.; Jones, G.; et al. The 2011 report on dietary reference intakes for calcium and vitamin D from the Institute of Medicine: What clinicians need to know. J. Clin. Endocrinol. Metab. 2011, 96, 53-58. [CrossRef]

151. Grant, W.B.; Karras, S.N.; Bischoff-Ferrari, H.A.; Annweiler, C.; Boucher, B.J.; Juzeniene, A.; Garland, C.F.; Holick, M.F. Do studies reporting 'U'-shaped serum 25-hydroxyvitamin D-health outcome relationships reflect adverse effects? Derm. Endocrinol. 2016, 8, e1187349. [CrossRef] [PubMed]

152. Holick, M.F.; Binkley, N.C.; Bischoff-Ferrari, H.A.; Gordon, C.M.; Hanley, D.A.; Heaney, R.P.; Murad, M.H.; Weaver, C.M.; Endocrine, S. Evaluation, treatment, and prevention of vitamin D deficiency: An Endocrine Society clinical practice guideline. J. Clin. Endocrinol. Metab. 2011, 96, 1911-1930. [CrossRef] [PubMed]

153. Veugelers, P.J.; Pham, T.M.; Ekwaru, J.P. Optimal Vitamin D Supplementation Doses that Minimize the Risk for Both Low and High Serum 25-Hydroxyvitamin D Concentrations in the General Population. Nutrients 2015, 7, 10189-10208. [CrossRef] [PubMed]

154. Pludowski, P.; Holick, M.F.; Grant, W.B.; Konstantynowicz, J.; Mascarenhas, M.R.; Haq, A.; Povoroznyuk, V.; Balatska, N.; Barbosa, A.P.; Karonova, T.; et al. Vitamin D supplementation guidelines. J. Steroid Biochem. Mol. Biol. 2018, 175, 125-135. [CrossRef]

155. Grant, W.B.; Boucher, B.J. A Review of the Potential Benefits of Increasing Vitamin D Status in Mongolian Adults through Food Fortification and Vitamin D Supplementation. Nutrients 2019, 11, 2452. [CrossRef]

156. Camargo, C.A., Jr.; Ganmaa, D.; Frazier, A.L.; Kirchberg, F.F.; Stuart, J.J.; Kleinman, K.; Sumberzul, N.; Rich-Edwards, J.W. Randomized trial of vitamin D supplementation and risk of acute respiratory infection in Mongolia. Pediatrics 2012, 130, e561-e567. [CrossRef]

157. Uwitonze, A.M.; Razzaque, M.S. Role of Magnesium in Vitamin D Activation and Function. J. Am. Osteopath Assoc. 2018, 118, 181-189. [CrossRef]

(C) 2020 by the authors. Licensee MDPI, Basel, Switzerland. This article is an open access article distributed under the terms and conditions of the Creative Commons Attribution (CC BY) license (http://creativecommons.org/licenses/by/4.0/). 